\title{
Komparasi Luas Bidang Datar dengan Determinan dan Rumus Baku
}

\author{
Ruslan Laisouw $^{1 凶}$ dan Dyah Safitri Qammariyah Kharie ${ }^{2}$ \\ 1 Staf Pengajar Fakultas MIPA, Universitas Muhammadiyah Maluku Utara. Ternate. Indonesia, \\ Email : ruslanlaisouw@gmail.com \\ 2 Mahasiswa Peminatan Epidemiologi Fakultas Ilmu Kesehatan, Universitas Muhammadiyah Maluku Utara. Ternate. \\ Indonesia, \\ Email : dyah safitri@yahoo.com \\ ${ }^{凶}$ Korespondensi : Ruslan Laisouw, Universitas Muhammadiyah Maluku Utara, Ternate, Indonesia, \\ Email : ruslanlaisouw@gmail.com
}

\begin{abstract}
ABSTRAK
Penulisan artikel ini difokuskan dalam penentuan luas bidang datar yang diketahui hanyalah titik-titik sudutnya dengan mengggunakan determinan dan rumus baku. Hasil perhitungan luas bidang datar yang menggunakan determinan akan lebih efektif dan efisien bila dibandingkan dengan menggunakan rumus baku.
\end{abstract}

\section{Keyword: Luas Bidang Datar, Determinan, Rumus Baku}

\section{PENDAHULUAN}

Beberapa bentuk bidang datar diantaranya adalah segitiga, segi empat, segi lima, segi enam, lingkaran dan masih banyak bidang datar lainnya. Untuk menghitung luas suatu bidang datar misalnya persegi, sering digunakan rumus baku yaitu panjang dikalikan lebar, namun yang menjadi masalah jika nilai-nilai tersebut tidak diketahui, hal ini menjadi pekerjaan yang sangat rumit dan memerlukan beberapa pendekatan untuk menentukn luasnya.

Salah satu pendekatan yang dapat digunakan untuk menyelesaikan permasalahan di atas yaitu dengan menggunakan konsep determinan. Untuk menggunakan konsep ini disyaratkan harus diketahui titik-titik sudut dari bidang datar yang dimaksud. Titik-titik sudut bangun datar dapat dipandang sebagai elemen-elemen didalam matriks. Sehingga penentuan luas dapat juga digunakan konsep determinan dalam matriks, sehingga penulisan artikel ini dengan tujuan untuk menetukan luas bidang datar dengan mengggunakan determinan dan rumus baku.

\section{Metode Penelitian} berikut:

Penelitian ini merupakan studi literatur (kajian pustaka) dengan tahap -tahapan sebagai 1) Pengumpulan Literatur

Pada tahap ini dilakukan pengumpulan literature maupun informasi yang diperlukan baik dari buku-buku, skripsii dan situs-situs internet yang membahas tentang Bidang Datar, Jarak, Matriks, Determinan Matriks dan Metode Saruss.

2) Pengkajian Literatur

Penelaahan isi sumber pustaka dengan cara membaca dan mempelajarinya, selanjutnya pengelompokan dan mencatat literatur-literatur tersebut sesuai dengan masalah yang akan dibahas.

3) Pengembangan Literatur

Pengembangan dilakukan dengan memberi uraian-uraian, untuk dapat lebih memahami konsep-konsep yang sudah ada.

4) Penyusunan Hasil Penelitian

Penyusunan hasil penelitian digunakan sebagai lagkah awal untuk memberi gambaran secara menyeluruh tentang topik yang akan dibahas. 


\section{HASIL DAN PEMBAHASAN}

\subsection{Hasil Perhitungan Luas Bidang Datar Menggunakan Determinan}

\subsubsection{Segi Empat}

Pada dasarnya bahwa terdapat banyak bentuk bangun datar segi empat, maka penulis hanya akan membahas 2 bentuk bidang datar yakni persegi panjang dan layang-layang.

a) Persegi panjang

Bidang datar persegi panjang $\mathrm{ABCD}$ terdiri atas dua bentuk segitiga yaitu $\triangle \mathrm{ABC}$ dan $\triangle \mathrm{ACD}$. Dari pernyataan tersebut maka luas dari bidang datar segi empat ABCD adalah:

$$
L=\left|\frac{1}{2}\right| \begin{array}{lll}
x_{1} & y_{1} & 1 \\
x_{2} & y_{2} & 1 \\
x_{3} & y_{3} & 1
\end{array}||+\left|\frac{1}{2}\right| \begin{array}{lll}
x_{1} & y_{1} & 1 \\
x_{3} & y_{3} & 1 \\
x_{4} & y_{4} & 1
\end{array}||
$$

Masalah 1:

$$
\text { Dimana A }\left(x_{1}, y_{1}\right), \mathrm{B}\left(x_{2}, y_{2}\right), \mathrm{C}\left(x_{3}, y_{3}\right) \text { dan D }\left(x_{4}, y_{4}\right)
$$

Hitunglah

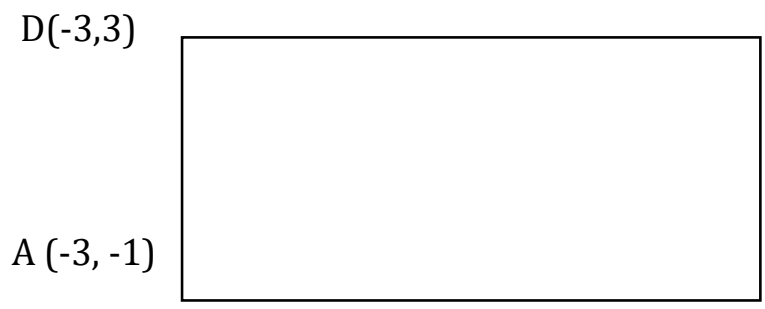

Peny:

Dari gambar di atas diketahui $A(-3,-1), B(3,-1), C(3,3)$ dan $D(-3,3)$ dan dibentuk oleh $\triangle \mathrm{ABC}$ dan $\triangle \mathrm{ACD}$. Dimana $A\left(x_{1}, y_{1}\right), B\left(x_{2}, y_{1}\right), \mathrm{C}\left(x_{2}, y_{2}\right)$ dan $\mathrm{D}\left(x_{1}, y_{2}\right)$.

Maka luas persegi panjang ABCD yaitu:

Atau:

$$
L=\left|\frac{1}{2}(|\triangle \mathrm{ABC}|+|\triangle A C D|)\right|
$$

$$
\begin{aligned}
L & =\left|\frac{1}{2}\left(\left|\begin{array}{lll}
x_{1} & y_{1} & 1 \\
x_{2} & y_{1} & 1 \\
x_{2} & y_{2} & 1
\end{array}\right|+\left|\begin{array}{lll}
x_{1} & y_{1} & 1 \\
x_{2} & y_{2} & 1 \\
x_{1} & y_{2} & 1
\end{array}\right|\right)\right| \\
|\Delta \mathrm{ABC}| & =\left|\begin{array}{lll}
x_{1} & y_{1} & 1 \\
x_{2} & y_{1} & 1 \\
x_{2} & y_{2} & 1
\end{array}\right|=\left|\begin{array}{ccc}
-3 & -1 & 1 \\
3 & -1 & 1 \\
3 & 3 & 1
\end{array}\right| \\
& =9+15=24 \\
|\Delta A C D| & =\left|\begin{array}{lll}
x_{1} & y_{1} & 1 \\
x_{2} & y_{2} & 1 \\
x_{1} & y_{2} & 1
\end{array}\right|=\left|\begin{array}{ccc}
-3 & -1 & 1 \\
3 & 3 & 1 \\
-3 & 3 & 1
\end{array}\right| \\
& =\left(\begin{array}{ll}
-9+3+9 & +-9-9-3
\end{array}\right)-\left(\begin{array}{ll}
-9-9 & -1
\end{array}\right) \\
& =3+21=24
\end{aligned}
$$

Sehingga diperoleh:

$$
\begin{aligned}
& L=\left|\frac{1}{2}\left(\left|\begin{array}{lll}
x_{1} & y_{1} & 1 \\
x_{2} & y_{2} & 1 \\
x_{3} & y_{3} & 1
\end{array}\right|+\left|\begin{array}{lll}
x_{1} & y_{1} & 1 \\
x_{3} & y_{3} & 1 \\
x_{4} & y_{4} & 1
\end{array}\right|\right)\right| \\
& \text { Luas } A B C D=\left|\frac{1}{2}(24+24)\right|=\left|\frac{1}{2}(48)\right|=24 .
\end{aligned}
$$

\section{b) Layang-layang}

Layang-layang dapat dibagi menjadi dua buah segitiga yang bentuk dan ukurannya sama. Sehingga Luas segitiga $A B C=$ Luas segitiga $A C D$. Dengan demikian maka: 
Luas Layang - layang $A B C D=$ Luas $\triangle A B C+\triangle A C D$

$$
=2 \times \text { Luas segitiga } A B C
$$

Sehingga Luas layang -layang $\mathrm{ABCD}$ adalah sebagai berikut:

$$
\begin{aligned}
\text { Luas Layang - layang } A B C D= & 2 \times\left|\frac{1}{2}\right| \begin{array}{lll}
x_{1} & y_{1} & 1 \\
x_{2} & y_{2} & 1 \\
x_{3} & y_{3} & 1
\end{array}|| \\
& =\left|\operatorname{det}\left[\begin{array}{lll}
x_{1} & y_{1} & 1 \\
x_{2} & y_{2} & 1 \\
x_{3} & y_{3} & 1
\end{array}\right]\right|
\end{aligned}
$$

Jadi luas layang-layang yaitu:

\section{Masalah 2:}

$$
\text { Luas Layang - layang } A B C D=\left|\operatorname{det}\left[\begin{array}{lll}
x_{1} & y_{1} & 1 \\
x_{2} & y_{2} & 1 \\
x_{3} & y_{3} & 1
\end{array}\right]\right|
$$

Tentukan luas layang-layang $\mathrm{ABCD}$ dengan titik $A(-5,0), B(-3,2), C(5,0)$ dan $D(-3,-2)$. Peny:

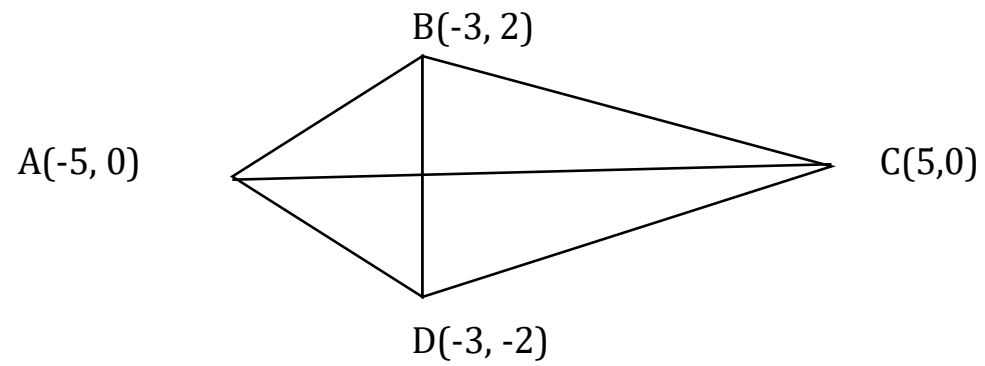

Dari gambar di atas dapat di bagi menjadi dua bentuk segitiga yaitu $\triangle \mathrm{ABC}$ dan $\triangle \mathrm{ACD}$. Dimana $\mathrm{A}$ $\left(x_{1}, y_{1}\right), \mathrm{B}\left(x_{2}, y_{2}\right), \mathrm{C}\left(x_{3}, y_{1}\right)$ dan $\mathrm{D}\left(x_{2}, y_{3}\right)$.

Maka:

$$
\begin{aligned}
& \text { Luas Layang - layang ABCD }=\left|\begin{array}{lll}
x_{1} & y_{1} & 1 \\
x_{2} & y_{2} & 1 \\
x_{3} & y_{3} & 1
\end{array}\right|=\left|\begin{array}{ccc}
-5 & 0 & 1 \\
-3 & 2 & 1 \\
5 & 0 & 1
\end{array}\right| \\
& =\left|\begin{array}{ccccc}
-5 & 0 & 1 & -5 & 0 \\
-3 & 2 & 1 & -1 & 2 \\
5 & 0 & 1 & 5 & 0
\end{array}\right| \\
& =\mid \begin{array}{l}
-10-10 \mid=20 \\
\text { Jadi luas layang-layang ABCD adalah 20. }
\end{array}
\end{aligned}
$$

\subsubsection{Segi Lima}

Segi lima beraturan terdiri atas lima bentuk segitiga. Sehingga luas segi lima yaitu: $L=5 \times L \Delta=5 \times\left|\frac{1}{2}\right| \begin{array}{lll}x_{1} & y_{1} & 1 \\ x_{2} & y_{2} & 1 \\ x_{3} & y_{3} & 1\end{array}||=\left|\frac{5}{2}\right| \begin{array}{lll}x_{1} & y_{1} & 1 \\ x_{2} & y_{2} & 1 \\ x_{3} & y_{3} & 1\end{array}||$

Jadi rumus luas segi lima adalah sebagai berikut:

$$
L=\left|\frac{5}{2}\right| \begin{array}{lll}
x_{1} & y_{1} & 1 \\
x_{2} & y_{2} & 1 \\
x_{3} & y_{3} & 1
\end{array}||
$$
lima.

Dimana $\left(x_{1}, y_{1}\right),\left(x_{2}, y_{2}\right)$ dan $\left(x_{3}, y_{3}\right)$ merupakan titik sudut segitiga dari bentuk bidang datar segi Masalah 3:

Hitunglah luas segi lima ABCDE dibawah ini dengan titik pusat $P=(0,0)$ 


\section{Peny:}

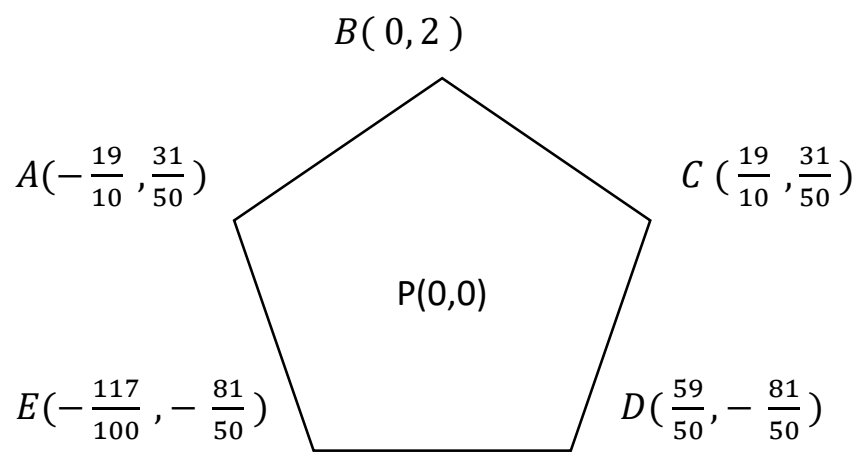

Diketahui titik pusat segi lima yaitu $P=(0,0)$, dengan titik dari masing-masing sudutnya yaitu $A\left(-\frac{19}{10}, \frac{31}{50}\right), B(0,2), C\left(\frac{19}{10}, \frac{31}{50}\right), D\left(\frac{59}{50},-\frac{81}{50}\right)$, dan $E\left(-\frac{117}{100},-\frac{81}{50}\right)$.

Misalnya di ambil salah satu bentuk segitiga yaitu $\triangle A B P$, maka luas segi lima ABCDE yaitu:

$$
\begin{aligned}
& L=\left|\frac{5}{2}\right| \begin{array}{lll}
x_{1} & y_{1} & 1 \\
x_{2} & y_{2} & 1 \\
x_{2} & y_{0} & 1
\end{array}||=\left|\frac{5}{2}\right| \begin{array}{ccc}
-\frac{19}{10} & \frac{31}{50} & 1 \\
0 & 2 & 1 \\
0 & 0 & 1
\end{array} \mid \\
& =\left|\frac{5}{2}\left(\left|\begin{array}{ccc:cc}
-\frac{19}{10} & \frac{31}{50} & 1 & \frac{19}{10} & \frac{31}{50} \\
0 & 2 & 1 & 0 & 2 \\
0 & 0 & 1 & 0 & 0
\end{array}\right|\right)\right| \\
& =\left|-\frac{190}{20}\right|=9,5 \text {. Jadi'luas segi lima adalah 9,5 }
\end{aligned}
$$

\subsubsection{Segi Enam}

Pada bab sebelumnya telah dibahas bahwa Segi enam biasa memiliki enam sisi dan sudut yang sama, yang terdiri atas enam buah segitiga sama sisi. Sehingga luas segi enam dapat dihitung dengan rumus:

$$
L=6 \times L \Delta=6 \times\left|\frac{1}{2}\right| \begin{array}{lll}
x_{1} & y_{1} & 1 \\
x_{2} & y_{2} & 1 \\
x_{3} & y_{3} & 1
\end{array}||=|3| \begin{array}{lll}
x_{1} & y_{1} & 1 \\
x_{2} & y_{2} & 1 \\
x_{3} & y_{3} & 1
\end{array}||
$$

Jadi rumus segi enam dapat dinyatakan sebagai berikut:

$$
L=|3| \begin{array}{lll}
x_{1} & y_{1} & 1 \\
x_{2} & y_{2} & 1 \\
x_{3} & y_{3} & 1
\end{array} \mid
$$

Dimana $\left(x_{1}, y_{1}\right),\left(x_{2}, y_{2}\right)$ dan $\left(x_{3}, y_{3}\right)$ merupakan titik sudut dari salah satu bentuk segitiga yang terbagi dari bentuk bidang datar segi enam.

\section{Masalah 4:}

Hitunglah luas segi enam ABCDEF pada gambar di bawah ini dengan titik pusat $P(0,0)$.

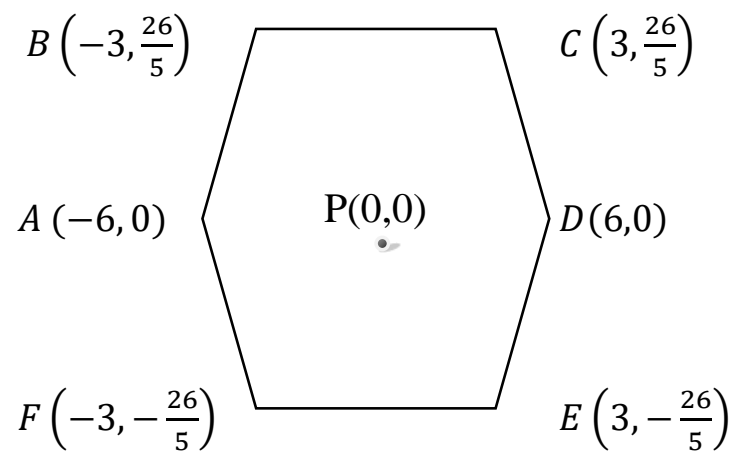




\section{Penye:}

Dari gambar diatas dapat diketahui bahwa bidang datar segi enam mempunyai titik pusat $\mathrm{P}(0$, $0)$ dan titik sudut $A(-6,0), B\left(-3, \frac{26}{5}\right), C\left(3, \frac{26}{5}\right), D(6,0), E\left(3,-\frac{26}{5}\right)$ dan $F\left(-3,-\frac{26}{5}\right)$.

Misalnya di hitung salah satu luas segitiga sama sisi yang berada dalam segi enam yaitu $\triangle A B P$. Maka luas segi enam ABCDEF yaitu:

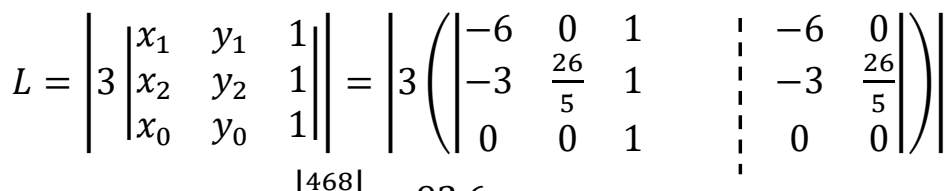

$$
\begin{aligned}
& =\left|\frac{468}{5}\right|=93,6
\end{aligned}
$$

Jadi luas segi enam ABCDEF yaitu 93,6.

\subsection{Hasil Perhitungan Luas Bidang Datar Menggunakan Rumus Baku 3.2.1. Segi Empat \\ a) Persegi panjang}

Sebelumnya telah dijelaskan bahwa untuk menghitung luas persegi panjang dapat digunakan rumus :

$$
L=\text { panjang }(p) \times \operatorname{lebar}(l)
$$

\section{Masalah 5:}

Hitunglah

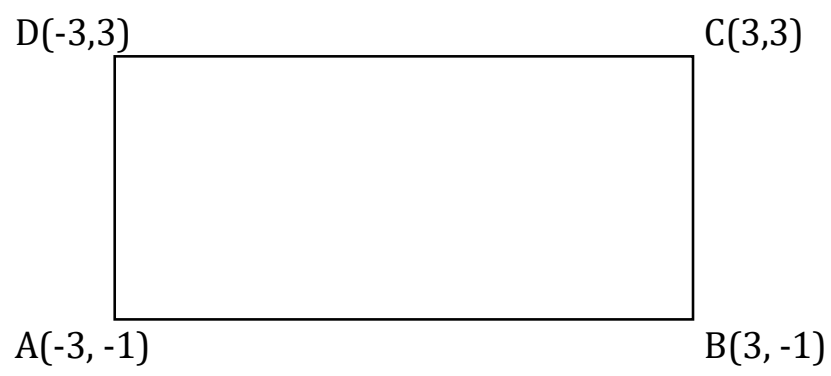

\section{Peny:}

Dari gambar di atas diketahui $A(-3,-1), B(3,-1), C(3,3)$ dan $D(-3,3)$ dan dibentuk oleh $\triangle \mathrm{ABC}$ dan $\triangle \mathrm{ACD}$. Untuk menghitung panjang dan lebar dapat digunakan rumus jarak yaitu : $d(A B)=\sqrt{\left(x_{2}-x_{1}\right)^{2}+\left(y_{1}-y_{1}\right)^{2}}$

Maka :

$$
\begin{aligned}
d(A B)=\sqrt{\left(x_{2}-x_{1}\right)^{2}+\left(y_{1-} y_{1}\right)^{2}} & \\
& =\sqrt{(3-(-3))^{2}+(-1-(-1))^{2}}=6
\end{aligned}
$$

Dari penyelesaian diatas kita mendapatkan panjang dari bidang datar persegi panjang yaitu 6.

$$
\begin{aligned}
d(B C) & =\sqrt{\left(x_{2}-x_{2}\right)^{2}+\left(y_{2-} y_{1}\right)^{2}} \\
= & \sqrt{(3-3)^{2}+(3-(-1))^{2}}=4
\end{aligned}
$$

Dari penyelesaian tersebut diperoleh nilai lebar yaitu 4 Sehingga:

$$
\begin{gathered}
\text { Luas }=\text { panjang }(p) \times \text { lebar }(l) \\
\text { Luas }=6 \times 4=24
\end{gathered}
$$

b) Layang-layang

Untuk menghitung luas bidang datar layang-layang dapat digunakan rumus sebagai berikut:

Masalah 6:

$$
\text { Luas Layang - layang }=\frac{1}{2} \times A C \times D B
$$

Tentukan luas layang-layang dengan titik $A(-5,0), B(-3,2), C(5,0)$ dan $D(-3,-2)$. 
Peny:

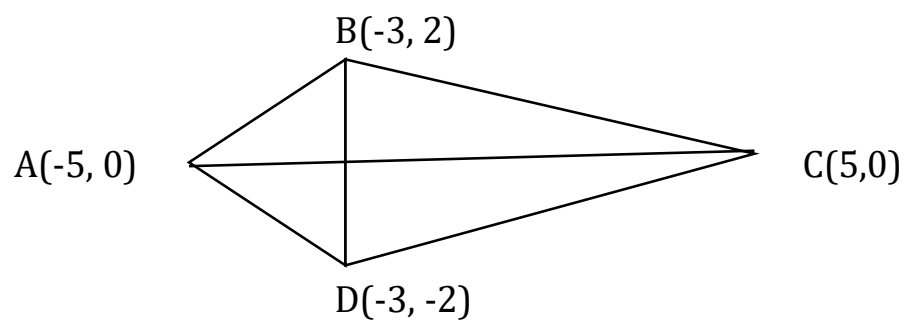
yaitu:

Untuk mencari panjang dari diagonal layang-layang di atas maka dapat digunakan rumus jarak

$$
\begin{aligned}
& d(A C)=\sqrt{\left(x_{3}-x_{1}\right)^{2}+\left(y_{1-} y_{1}\right)^{2}}=\sqrt{(5-(-5))^{2}+(0-0)^{2}}=10 \\
& d(B D)=\sqrt{\left(x_{2}-x_{2}\right)^{2}+\left(y_{3}-y_{2}\right)^{2}}=\sqrt{(-3-(-3))^{2}+(-2-2)^{2}}=4
\end{aligned}
$$

Sehingga luas layang-layang ABCD yaitu:

$$
\begin{aligned}
\text { Luas Layang - layang }=\frac{1}{2} \times A C & \times D B \\
& =\frac{1}{2} \times 10 \times 4=20
\end{aligned}
$$

\subsubsection{Segi Lima}

Segi lima adalah segi banyak yang memiliki lima sisi. Semua sisinya memiliki panjang yang sama. Dan, seluruh sudutnya sama besar $\left(108^{0}\right)$. Untuk menghitung luas segi lima beraturan, bisa digunakan rumus sebagai berikut:

\section{Masalah 7:}

$$
\text { Luas }=n \times L \Delta=5 \times L \Delta
$$

Hitunglah luas segi lima pada gambar dibawah ini dengan titik pusat $(0,0)$.

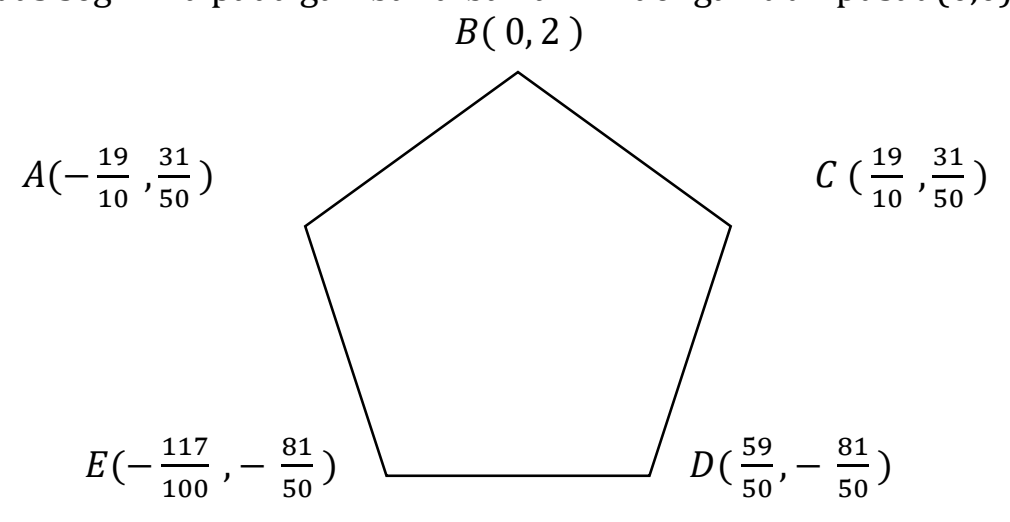

Peny:

Diketahui titik pusat segi lima yaitu $P=(0,0)$, dengan titik dari masing-masing sudutnya yaitu $A\left(-\frac{19}{10}, \frac{31}{50}\right), B(0,2), C\left(\frac{19}{10}, \frac{31}{50}\right), D\left(\frac{59}{50},-\frac{81}{50}\right)$, dan $E\left(-\frac{117}{100},-\frac{81}{50}\right)$. Untuk menghitung luas segi lima beraturan, bisa digunakan rumus sebagai berikut: Luas $=n \times L \Delta=5 \times L \Delta$

Untuk menghitung $L \Delta$ dapat mengunakan rumus $L \Delta=\frac{1}{2}$ (alas)(ting gi)

Misalnya $L \triangle A B P=\frac{1}{2}$ (alas) (tinggi)

Nilai alas dapat diperoleh menggunakan rumus jarak yaitu:

$$
\text { Sehingga: } \quad d(A B)=\sqrt{\left(x_{2}-x_{1}\right)^{2}+\left(y_{2-} y_{1}\right)^{2}}
$$

$$
d(A B)=\sqrt{\left(0-\left(-\frac{19}{10}\right)\right)^{2}+\left(2-\frac{31}{50}\right)^{2}}
$$




$$
=\sqrt{5,514}=2,35
$$

Untuk menghitung tinggi kita membutuhkan rumus titik tengah yaitu:

Misalkan titik tengah $\mathrm{AB}=\mathrm{T}$, sehingga :

$$
A B=\left(\frac{x_{1}+x_{2}}{2}, \frac{y_{1}+y_{2}}{2}\right)
$$

$$
T=\left(\frac{-\frac{19}{10}+0}{2}, \frac{\frac{31}{50}+2}{2}\right)=\left(-\frac{19}{20}, \frac{131}{100}\right)
$$
diperoleh;

Untuk menghitung tinggi segitiga dapat menggunakan rumus jarak antara $\mathrm{T}$ dan titip P sehingga

$$
\begin{aligned}
d(T P) & =\sqrt{\left(0-\left(-\frac{19}{20}\right)\right)^{2}+\left(0-\frac{131}{100}\right)^{2}} \\
& =\sqrt{\left(-\frac{19}{20}\right)^{2}+\left(\frac{131}{100}\right)^{2}} \\
& =1,62
\end{aligned}
$$

Sehingga diperoleh $L \Delta=\frac{1}{2}$ (alas) (ting gi $)=\frac{1}{2}(2,35)(1,62)=\frac{3,807}{2}=1,9$

Maka luas segi lima beraturan, sebagai berikut:

\subsubsection{Segi Enam}

$$
\text { Luas }=n \times L \Delta=5 \times L \Delta=5 \times 1,9=9,5
$$

Rumus untuk menghitung luas segi enam adalah sebagai berikut:

Masalah 8:

$$
\text { Luas }=\frac{\left(3 \sqrt{3} \times s^{2}\right)}{2}
$$

Hitunglah luas segi enam dengan titik sudut $A(-6,0), B\left(-3, \frac{26}{5}\right), C\left(3, \frac{26}{5}\right), D(6,0), F\left(-3,-\frac{26}{5}\right)$ dan $E\left(3,-\frac{26}{5}\right)$

Peny:

Diketahui: $A=(-6,0), B\left(-3, \frac{26}{5}\right), C\left(3, \frac{26}{5}\right), D(6,0), F\left(-3,-\frac{26}{5}\right)$ dan $\quad E\left(3,-\frac{26}{5}\right)$. Untuk menghitung luas segi enam dapat digunakan rumus sebagai berikut: $\quad$ Luas $=\frac{\left(3 \sqrt{3} \times s^{2}\right)}{2}$

Dimana: $s=$ sisi bidang datar segi enam

Untuk menghitung panjang sisi bidang datar dapat digunakan rumus jarak yaitu:

$$
d(P Q)=\sqrt{\left(x_{2}-x_{1}\right)^{2}+\left(y_{2-} y_{1}\right)^{2}}
$$

Misalnya untuk menghitung panjang dari sisi BC yang membentuk bidang datar segienam yaitu:

$$
\begin{aligned}
d(A B) & =\sqrt{(-3-(-6))^{2}+\left(\frac{26}{5}-0\right)^{2}}=\sqrt{\left(x_{2}-x_{1}\right)^{2}+\left(y_{2-} y_{1}\right)^{2}} \\
& =6,00333
\end{aligned}
$$

Jadi panjang sisi $B C=6,00333$ atau $s=6,00333$ sehingga $s^{2}=36,04$

$$
\begin{aligned}
& \text { Luas segi enam }=\frac{\left(3 \sqrt{3} \times s^{2}\right)}{2} \\
& \text { Luas segi enam }=\frac{(3 \sqrt{3} \times 36,04)}{2}=\frac{(108.12 \sqrt{3})}{2}=54.06 \sqrt{3}=93,6
\end{aligned}
$$




\subsection{Pembahasan}

\subsubsection{Perbandingan menentukan luas bidang datar menggunakan determinan dan rumus baku}

Perbandingan menentukan luas bidang datar menggunakan determinan dan rumus baku, dapat dilihat dari hasil perhitungan dan banyaknya langkah penyelesaian.

\section{Langkah Penyelesaian Dan Hasil Perhitungan Luas Bidang Datar Menggunakan Determinan.}

Dalam menyelesaikan perhitungan luas menggunakan determinan, bidang datar segi empat, segi lima dan segi enam terlebih dahulu dibagi menjadi beberapa bagian bentuk segitiga yang kongruen.

\section{1) Segi Empat}

Perhitungan luas segi empat menggunakan determinan dapat di tentukan dengan satu langkah penyelesaian yaitu dengan cara memasukan titik-titik sudut yang diketahui dalam rumus penentuan luas bidang datar segi empat. Dari hasil perhitungan luas bidang datar, seperti yang terlihat dalam soal 1 persegi panjang, memperoleh hasil perhitungan luas yaitu 24. Sedangkan pada hasil perhitungan luas layang-layang seperti dalam soal 2 memperoleh hasil perhitungan luas yaitu 20.

2) Segi lima

Perhitungan luas segi lima menggunakan determinan membutuhkan satu langkah penyelesaian yaitu memasukan langsung titik sudut dari salah satu bidang datar segitiga yang terbentuk dari bidang datar segi lima ke dalam rumus bidang datar segi lima. Dari perhitungan luas segi lima memperoleh hasil yaitu 9,5. Langkah dan hasil perhitungan tersebut dapat dilihat pada soal 3.

3) Segi enam

Pada soal 4. Perhitungan luas menggunakan determinan membutuhkan satu langkah penyelesaian yaitu, langsung memasukan titik sudut dari salah satu bidang datar segitiga yang telah dibentuk dari bidang datar segi enam ke dalam rumus mencari luas bidang datar segi enam. Sehinggga hasil perhitungan luas bidang datar segi enam yang diperoleh yaitu 93,6.

2. Langkah Penyelesaian Dan Hasil Perhitungan Luas Bidang Datar Menggunakan Rumus Baku.

Dalam menyelesaikan perhitungan luas bidang datar menggunakan rumus baku. Jika diketahui titik-titik sudutnya, dapat dilakukan dengan beberapa langkah sebagai berikut:

1) Segi empat

Bentuk bidang datar segi empat yang di bahas dalam penelitian ini adalah persegi panjang dan layang-layang.

a) Persegi panjang

Untuk menghitung luas persegi panjang menggunakan rumus baku membutuhkan tiga langkah penyelesaian yaitu mencari panjang sisi terlebih dahulu dengan menggunakan rumus jarak, kemudian menentukan lebar sisi persegi panjang dengan menggunakan rumus jarak, langkah selanjutnya memasukan nilai dari panjang dan lebar sisi yang telah di dapat ke dalam rumus persegi panjang yang akan di gunakan. Dari langkah-langkah tersebut diperoleh hasil perhitungan yaitu 24. Langkah dan hasil perhitungan tersebut dapat dilihat pada soal 5.

b) Layang-layang

Pada soal 6. Perhitungan luas layang-layang dapat ditentukan dengan tiga langkah penyelesaian seperti, menghitung panjang diagonal sisi terpendek menggunakan rumus jarak, kemudian menghitung panjang diagonal sisi terpanjang mengunakan rumus jarak, selanjutnya memasukan nilai panjang dari masing-masing diagonal yang telah diketahui ke dalam rumus luas layang-layang untuk mendapatkan hasil perhitungan. Dari langkah-langkah tersebut maka diperoleh hasil perhitungan luas layang-layang yaitu 20.

2) Segi lima

Segi lima beraturan di bagi menjadi lima bentuk segitiga yang kongruen dan dibutuhkan hanya salah satu bentuk segitiga untuk memperoleh hasil luas perhitungan segi lima. Sesuai pada Pada soal 7. Diperoleh hasil perhitungan luas yaitu 9,5. Hasil tersebut didapat dengan 4 langkah penyelesaian yaitu:

a) Menenetukan panjang sisi alas segitiga dengan menggunakan rumus jarak

b) Mencari tinggi bidang datar segitiga menggunakan rumus titik tengah dan rumus jarak.

c) Menentukan luas segitiga dengan cara memasukan nilai alas dan tinggi yang telah di dapat ke dalam rumus luas segitiga. 
d) Memasukan hasil perhitungan luas segitiga ke dalam rumus segi lima.

\section{3) Segi enam}

Pada soal 8. Hasil perhitungan luas bidang datar segi enam yaitu 93,6. Hasil tersebut diperoleh dengan dua langkah yaitu dengan mencari panjang dari sisi segi enam menggunakan rumus jarak, kemudian nilai panjang yang telah di dapat di masukan ke dalam rumus segi enam. Berdasarkan hasil penelitian di atas, diperoleh bahwa hasil perhitungann luas bidang datar yang jika titik-titik sudutnya diketahui menggunakan determinan dan rumus baku dari sisi kecepatan penyelesaian, diperoleh bahwa perhitungan luas bidang datar menggunakan determinan lebih cepat langkah penyelesaiannya di bandingkan dengan menggunakan rumus baku. Hal ini dalam menggunakan determinan tidak terlalu banyak langkah yang dibutuhkan, yaitu hanya dengan memasukan titik sudut bidang datar yang di ketahui ke dalam rumus yang akan digunakan. Sedangkan pada perhitungan luas bidang datar menggunakan rumus baku terdapat beberapa langkah misalnya langkah pertama yang dilakukan yaitu mencari panjang sisi dari masing-masing bidang datar dengan menggunakan rumus jarak, langkah selanjutnya memasukan nilai dari panjang sisi yag telah di dapat kedalam rumus baku, selain langkahlangkah dan rumus tersebut ada bentuk bidang datar juga yang membutuhkan rumus titik tengah untuk proses perhitungan luas, misalnya pada bidang datar segitiga, yang nantinya hasil perhitungan luas segitiga ini akan digunakan untuk mencari luas segi lima.

\section{PENUTUP}

Komparasi hasil yang diperoleh sebagai berikut:

1. Perhitungan luas bidang datar jika titik-titik sudutnya diketahui menggunakan determinan akan lebih efektif dan efisien dibandingkan dengan menggunakan rumus baku.

2. Perhitungan luas bidang datar menggunakan determinan dapat ditentukan jika bidang datar tersebut dibagi menjadi beberapa bentuk segitiga.

\section{DAFTAR PUSTAKA}

Anton, Howard. 1987. Aljabar Linier Elementer.Jakarta: Erlangga.

Djafar, Djubaida. 2011. Menentukan Luas dan Persamaan Bidang Datar Menggunakan Matriks (Skripsi). Ternate: Universitas Muhammadiyah Maluku Utara (UMMU) Ternate.

Irawan, Etsa Indra dan Dwi Haryanto. 2012. 1700 Bank Soal Bimbingan Pemantap Matematika Untuk SMP/MTs. Yrama Widya.

JR, Frank Ayres.1994. Matriks (Versi SI/Metrik). Jakarta: Erlangga.

Krismanto, Al. 2004. Dimensi Tiga Pembelajaran Jarak. http://p4tkmatematika.org/download//ppp/PPP04 jarak.pdf. diakses pada tanggal 25 februari 2016.

Pramono, Sigit. 2015. Cerdas Kupas Tuntas Matematika SD/MI Kelas V. Yogyakarta:Laksana.

Pujiati dan Sigit GT. 2009. Pembelajaran Pengukuran Luas Bangun Datar dan Volume Bangun Ruang di SD. https://mgmpmatsatapmalang.filles.wordpress.com./2011/10/5-pembpengukuranluasbgndatarvol-bgnruangdisd.pdf. diakses pada tanggal 6 juli 2016.

Ruminta.2014. Matriks Persamaan Linier Dan Pemograman Linier. Bandung: Rekayasa Sains.

Supranto,J.1984. Pengantar Matrix. Jakarta: Fakultas Ekonomi Universitas Indonesia.

Saefudin, Abdul Aziz. 2012. Aljabar Matriks. Yogyakarta: Graha Ilmu.

Varberg,Dale , Edwin J. Purcell dan Steven E. Rigdon. 2010. Kalkulus Edisi Kesembilan jilid 1. Jakarta: Erlangga. 